\title{
Utilization of Randayan Island Coastal and Small Islands Protected Area for Development of Sustainable Diving Tourism
}

\author{
Enjang Hernandi Hidayat ${ }^{1}$, Parikesit $^{2}$, and Yudi Nurul Ihsan ${ }^{3}$ \\ ${ }^{1}$ Environment Science Program, Postgraduate School, Universitas Padjadjaran, Indonesia \\ ${ }^{2}$ Center for Environment and Sustainability Science, Universitas Padjadjaran, Indonesia \\ ${ }^{3}$ Faculty of Fisheries and Marine Science, Universitas Padjadjaran, Indonesia
}

\begin{abstract}
Randayan Island and The Surrounding Water Small Island Park (TPK Pulau Randayan dan Perairan Sekitarnya) is one of the Coastal and Small Islands Protected Areas (MPA) in West Kalimantan which has the potential to be developed into a marine tourism destination, especially sustainable diving tourism. The area has resources with a high level of diversity such as coral reefs, coral fish, seagrass, and other potential aquatic biota. This study aims to identify potentials, conduct resource suitability analysis, calculate the carrying capacity of the area, the carrying capacity of utilization, and make a map of area utilization suitability for the development of sustainable diving tourism. This research uses quantitative methods with tourism suitability analysis based on Yulius, et al (2018) and carrying capacity analysis based on Yulianda (2019). The data source is secondary data obtained from previous research and from publications published by several related agencies. The results showed that the Tourism Suitability Index for diving tourism in the limited use zone of Randayan Island Small Island Park consisted of Station 1 (Pulau Kabung), Station 2 (Pulau Lemukutan), Station 3 (Pulau Penata Besar), and Station 4 (Pulau Randayan) are included in the Conditional Suitable category, with scores of $65 \%, 56 \%, 72 \%, 65 \%$, respectively. The Area Carrying Capacity at each station are 596, 1,354, 1,028, 157 people per day, with the Utilization Carrying Capacity of 59, 135, 102, and 15 people per day.
\end{abstract}

\section{Introduction}

Maritime tourism contributes a significant amount of foreign exchange from the tourism sector considering the 10 National Tourism Strategic Areas (KSPN) that have been established, 7 of which are located in coastal areas and small islands. As a driving force for regional economic improvement, tourism has important benefits, namely as a job creation, growing many small and medium scale economic opportunities and can increase efforts to protect and improve the environment [3].

The role of marine tourism tends to increase in national development, given that the number of tourist visits to various marine tourism objects continues to increase. For Indonesia, in addition to contributing to the country's foreign exchange, tourism is expected to improve international relations, community empowerment and equal employment and income opportunities. Tourism activities are also able to contribute revenue to local governments through taxes and levies. In addition, tourism can create jobs and be a source of income for local residents and attract investors from outside the region [4]. The national development priority in the tourism sector, especially marine tourism, is also intended to improve the welfare of coastal communities through increasing income.

Apart from positive impacts, tourism can also have a negative impact on the developed areas. Lack of planning in managing tourist areas has resulted in various very detrimental impacts. Generally, these impacts result in a decrease in environmental quality which is then often followed by changes in the culture of the local community. This decline in environmental quality and cultural changes has spurred a reduction in market demand for tourism in the area, thus providing economic losses for the region [10]. Utilization that is carried out without a clear direction will result in the destruction of these sources, which in turn will kill tourism itself [3].

Maritime tourism destinations that are continuously being developed by the government are no exception in the National Marine Protected Area (KKPN) and Regional Water Conservation Area (KKPD). Not only 7 KKPN and 8 KKPD that have been listed in the 20202024 RPJMN target, but in several new conservation areas. One of the new conservation areas that has the potential to be developed into Dewi Bahari is the Randayan Island Small Island Park (TPK).

Small Island Park (TPK) Randayan Island is one of the conservation areas in West Kalimantan which has the potential to be developed into a marine tourism destination, especially sustainable diving tourism. Administratively, the Small Island Park (TPK) of Randayan Island belongs to Bengkayang Regency, West Kalimantan Province. This area has potential resources

* Corresponding author: hernandhy@gmail.com 
with a high level of diversity, such as coral reefs, coral fish, seagrass, and other potential aquatic biota.

Lemukutan Island, one of the inhabited islands in the Randayan Island TPK conservation area, is a favorite marine tourism destination for the community. Based on data from the Tourism Awareness Group (POKDARWIS) on Lemukutan Island, throughout 2017 there were 7,535 tourists who stayed at all Lemukutan Island inns. In addition, there is Randayan Island which is also a tourist destination in the Randayan Island TPK which offers beach tours, snorkeling and diving. There are several inns and resorts that can be rented by tourists visiting the island.

To be able to utilize the existing resources in the coastal conservation area and small islands of the Randayan Island TPK optimally, sustainably and sustainably and as an effort to develop the conservation area as a marine tourism destination, especially for the diving tourism category, holistic research is related to the potential, suitability and carrying capacity of the area really need to be done. This study aims to identify potentials, conduct resource suitability analysis, calculate the carrying capacity of the area, and create a map of the suitability of the use of the area for the development of sustainable diving tourism.

\section{Material and Methods}

\subsection{Study Site}

This research was carried out in the Coastal and Small Islands Protected Area (KKP3K), the Small Island Park (TPK) of Randayan Island and the surrounding waters in Bengkayang Regency, West Kalimantan Province. The conservation area which is the research location is a limited use zone with an area of $59,560.43$ ha or $96.64 \%$ of the total TPK area of Randayan Island and its surrounding waters. When the research was conducted in September 2020. Data was collected at 4 stations, namely Station 1 (Kabung Island), Station 2 (Lemukutan Island), Station 3 (Penata Besar Island), and Station 4 (Randayan Island). Determination of the station using purposive sampling method which is based on the consideration that the selected station can represent the limited use zone area of the Small Island Park (TPK) Randayan Island and its surrounding waters as a whole.

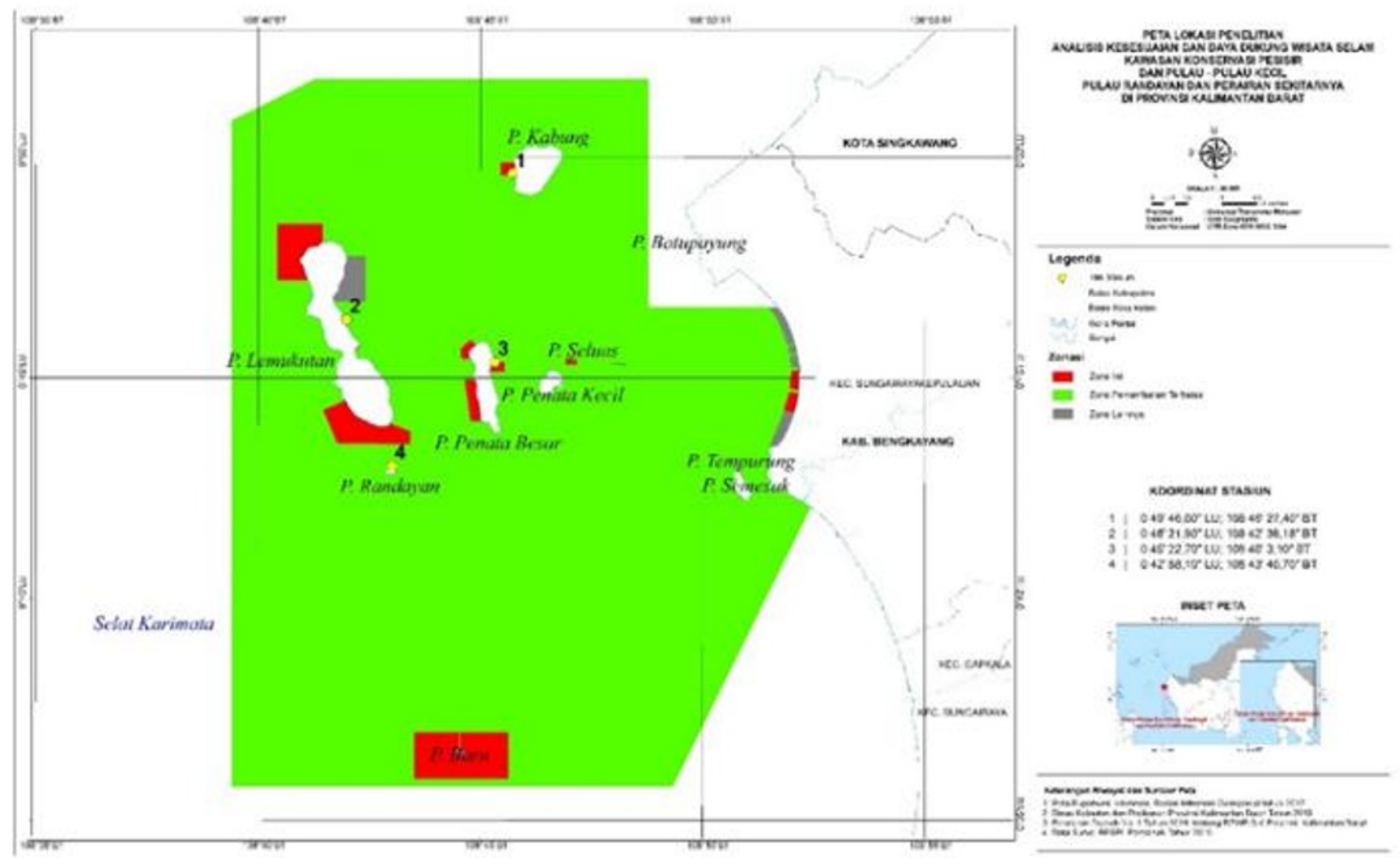

Figure 1. Study Area Map.

\subsection{Types and Sources of Data}

The data collected in this study are secondary data obtained from previous research and from publications published by several related agencies in this study. According to [6], secondary data is information obtained not directly from respondents, but from third parties. The types and sources of data required in this study are as follows. 
Tabel 1. Types and Sources of Research Data

\begin{tabular}{|c|c|c|c|}
\hline No. & Parameter & $\begin{array}{l}\text { Type of } \\
\text { Data }\end{array}$ & $\begin{array}{l}\text { Sources of } \\
\text { Data }\end{array}$ \\
\hline 1 & $\begin{array}{l}\text { Water } \\
\text { clarity (\%) }\end{array}$ & Secondary & $\begin{array}{l}\text { Management and } \\
\text { Zoning Plans } \\
\text { (RPZ) } \\
\text { Small Islands Park } \\
\text { (TPK) } \\
\text { Randayan and } \\
\text { Aquatic Area }\end{array}$ \\
\hline 2 & $\begin{array}{l}\text { Current } \\
\text { velocity (cm } \\
\text { / sec) }\end{array}$ & Secondary & $\begin{array}{l}\text { RPZ TPK } \\
\text { Randayan And } \\
\text { Surrounding } \\
\text { Waters / } \\
\text { Process data } \\
\text { from Copernicus }\end{array}$ \\
\hline 3 & $\begin{array}{l}\text { Cover } \\
\text { community } \\
\text { coral }(\%)\end{array}$ & Secondary & $\begin{array}{l}\text { RPZ } \\
\text { TPK Randayan and } \\
\text { the surrounding } \\
\text { waters }\end{array}$ \\
\hline 4 & $\begin{array}{l}\text { Coral } \\
\text { reef } \\
\text { depth }(\mathrm{m})\end{array}$ & Secondary & $\begin{array}{l}\text { RPZ } \\
\text { TPK Randayan and } \\
\text { the surrounding } \\
\text { waters }\end{array}$ \\
\hline 5 & $\begin{array}{l}\text { Type } \\
\text { of life } \\
\text { form }\end{array}$ & Secondary & $\begin{array}{l}\text { RPZ } \\
\text { TPK Randayan and } \\
\text { the surrounding } \\
\text { waters }\end{array}$ \\
\hline 6 & $\begin{array}{l}\text { Types of } \\
\text { reef } \\
\text { fish }\end{array}$ & Secondary & $\begin{array}{l}\text { RPZ } \\
\text { TPK Randayan and } \\
\text { the surrounding } \\
\text { waters }\end{array}$ \\
\hline 7 & $\begin{array}{l}\text { Vast } \\
\text { expanse } \\
\text { of coral }\end{array}$ & Secondary & $\begin{array}{l}\text { RPZ TPK } \\
\text { Randayan and } \\
\text { Aquatic Area / } \\
\text { Citra Satelit }\end{array}$ \\
\hline 8 & $\begin{array}{c}\text { Description of } \\
\text { the research } \\
\text { location }\end{array}$ & Secondary & $\begin{array}{l}\text { Pontianak BPSPL } \\
\text { Agency Report and } \\
\text { Related Research }\end{array}$ \\
\hline
\end{tabular}

\subsection{Data Analysis}

This study uses descriptive analysis to analyze the data that has been obtained. Descriptive analysis is an analysis used to describe or provide an overview or description of certain data or characteristics obtained in the field.

\subsubsection{Suitability Area Analysis}

Suitability analysis of water areas for marine tourism activities is carried out based on spatial concept. This analysis uses GIS modeling based on needs and analytics. Analysis based on spatial data concepts such as overlay, clip, intersect, buffer, query, union, merge; which can be selected or combined. The suitability of the area can be determined with certain parameters, which vary for each activity. Each parameter has a level of importance that is represented by a weighted value, and its condition status is based on the parameter score Yulianda (2019). As for the suitability parameters of resources for each category of marine tourism, especially sustainable diving tourism in this study refers to Yulius, et al. (2018) in the Book Criteria Guidelines for Establishing Marine Ecotourism Zones, as follows.

Tabel 2. Resource Suitability Matrix for Dive Tourism Category

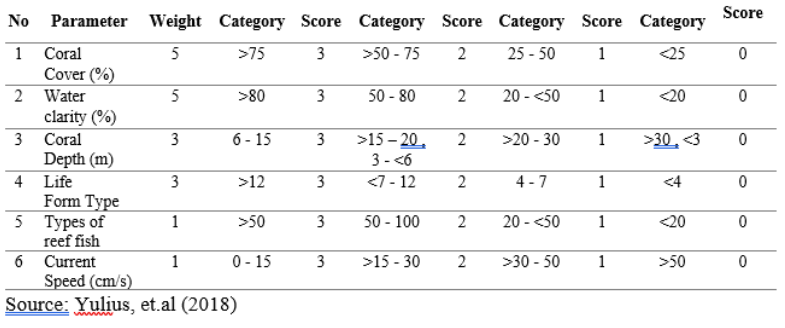

Furthermore, according to Yulius, et al (2018), the formula used to calculate the Tourism Suitability Index is as follows :

$$
I K W=\sum_{n=0}^{n}\left(\frac{N i}{N \max }\right) \times 100
$$

Where; IKW: tourism suitability index; $\mathrm{Ni}$ : the value of the referred parameter (weight $\mathrm{x}$ score); $\mathrm{N}$ max: maximum value of a tourism category ( $\mathrm{N}$ maximum dive tours $=54)$. Classification : Suitable if the IKW value: 75 - 100\%; Conditionally Suitable: $50-<75 \%$; and Unsuitable: $<50 \%$.

\subsubsection{Area Carrying Capacity Analysis}

Area Carrying Capacity (DDK) is the maximum number of visitors who can physically be accommodated in the area provided at a certain time without causing disturbance to nature and humans [8]. Equation for Area Carrying Capacity (DDK) in formula form is :

$$
D D K=K \times \frac{L p}{L t} \times \frac{W t}{W p}
$$

Where; DDK: Regional Carrying Capacity; K: Ecological potential of visitors per unit area (person); Lp: Area (m2) or long area (m) that can be utilized; Lt: Unit area for certain categories (m2); Wt: Time provided by the area for tourism in 1 day (hour); Wp: Time spent by visitors for any particular activity (hours).

In the DDK calculation, there are numbers that have been determined in each tourism category, for diving $\mathrm{K}$ $=2, \mathrm{Wp}=2, \mathrm{Wt}=8$, and $\mathrm{Lt}=2000 \mathrm{~m}^{2}$. Lp is calculated from the area or length of the area that can be used for ecotourism diving in an area. Tourism exploration in conservation is regulated by the provisions of Government Regulation No.18 / 1994 concerning Exploitation of Nature Tourism in National Park Use Zones and natural tourism parks, so the area that is allowed to be developed is $10 \%$ of the area of the utilization zone. So that DDK in conservation areas 
needs to be limited by the Utilization Carrying Capacity (DDP) with the formula DDP $=0.1 \times$ DDK [8].

\section{Result and Discussion}

Small Islands Park (TPK) of Randayan Island is administratively located in Bengkayang Regency, West Kalimantan Province. Part of Bengkayang Regency area is sea water area. Bengkayang Regency has 12 islands, 6 islands uninhabited and 6 islands already inhabited. All of these islands are located in the waters of Sungai Raya District. The largest inhabited islands are Lemukutan Island and Penata Besar Island (BPSPL Pontianak, 2019). Bengkayang Regency waters area is an area rich in natural marine resources. The area has aquatic ecosystems with a high level of diversity such as coral reef ecosystems, seagrass ecosystems, mangrove ecosystems, and also potential fishery resources that are very potential for the surrounding community.

Based on Government Regulation Number 60 of 2007 concerning Conservation of Fish Resources, Article 30 paragraph (2) states that the use of marine conservation areas is carried out in the form of fishing, fish breeding, aquatic nature tourism or research and education. [2] added that the implementation of the use of a marine conservation area must refer to the management plan and designation of each zone. The allocation of utilization space in conservation areas is carried out based on zoning of the area. The conservation area of the Randayan Island TPK reaches $61,633.7$ ha with zoning consisting of: the core zone has an area of $1,721.03$ ha or $2.79 \%$ of the area of the conservation area, the limited use zone has an area of $59,577.61$ ha or $96.63 \%$ of the area. the area of the conservation area, and other zones that have an area of
355.06 ha or $0.58 \%$ of the area of the conservation area [1].

Resource parameters related to diving tourism are the percentage of coral cover, water transparency, depth of coral reefs, types of life form, types of reef fish, current speed, and also the area of coral reef. The percentage of live coral cover on Kabung Island was $32.9 \%$, Lemukutan Island $24.22 \%$, Penata Besar Island 51.2, and Randayan Island 41.35\%. Brightness at the 4 study sites was $100 \%$ with an average current speed of $12 \mathrm{~cm} / \mathrm{s}$. The 3 research locations have an average depth of coral reefs suitable for the development of diving tourism, namely at a depth of 6-15 meters, while in Penata Besar Island, the depth of the coral reefs is 4-6 meters. The types of life form on the islands of Kabung, Lemukutan, Penata Besar, and Randayan were $9,8,8$, and 11 , respectively, with $25,35,31$, 41 species of reef fish, respectively. The results of data processing on the total area of coral reefs in the limited use zone of Kabung Island were \pm $452978.18 \mathrm{~m} 2$, Lemukutan Island \pm 1397716.86 $\mathrm{m} 2$, Penata Besar Island $\pm 502103.78 \mathrm{~m} 2$, and \pm $95007.98 \mathrm{~m} 2$ in Randayan Island.

Furthermore, a map of the suitability of diving tourism in the Small Islands Park of Randayan Island And Surrounding Waters is prepared to make it easier for visitors to determine diving tourism spots and also as a guide for conservation area managers in determining the number of tourists allowed to carry out diving tourism activities in accordance with the carrying capacity of the utilization of the conservation area. The dive tourism suitability map is as follows :

Tabel 3. Results of the Suitability Assessment for Dive Tourism in the TPK of Randayan Island and Surrounding Waters

\begin{tabular}{|c|c|c|c|c|c|c|c|c|c|}
\hline \multirow{2}{*}{ No } & \multirow{2}{*}{ Location } & \multicolumn{2}{|c|}{ Coordinate } & \multirow{2}{*}{$\begin{array}{c}\text { Coral Cover } \\
(\%)\end{array}$} & \multirow{2}{*}{$\begin{array}{l}\text { Coral Extent } \\
\text { (m2) }\end{array}$} & \multirow{2}{*}{ Lp } & \multirow{2}{*}{ Lt } & \multirow{2}{*}{$\begin{array}{c}\text { Area } \\
\text { Carrying } \\
\text { Capacity }\end{array}$} & \multirow{2}{*}{$\begin{array}{l}\text { Utilization } \\
\text { Camying } \\
\text { Capacity }\end{array}$} \\
\hline & & Latitude & Longitude & & & & & & \\
\hline 1 & Kabung $|s|$ and & $0^{\circ} 49^{\prime} 46,00^{\prime \prime} \mathrm{N}$ & $108^{\circ} 46^{\prime} 27,40^{\prime \prime} \mathrm{E}$ & 32,9 & 452978,18 & 149029,82 & 2000 & 596 & 59 \\
\hline 2 & $\begin{array}{l}\text { Lemukutan } \\
\text { Island }\end{array}$ & $0^{\circ} 46^{\prime} 21,90^{\prime \prime} \mathrm{N}$ & $108^{\circ} 42^{\prime} 38,18^{\prime \prime} \mathrm{E}$ & 24,22 & 1397716,86 & 338527,02 & 2000 & 1354 & 135 \\
\hline 3 & $\begin{array}{c}\text { Penata Besar } \\
\text { Island }\end{array}$ & $0^{\circ} 45^{\prime} 22,70^{\prime \prime} \mathrm{N}$ & $108^{\circ} 46^{\prime} 3,10^{\prime \prime} \mathrm{E}$ & 51,2 & 502103,78 & 257077,13 & 2000 & 1028 & 102 \\
\hline 4 & Randayan Island & $0^{\circ} 42^{\prime} 58,10^{\prime \prime} \mathrm{N}$ & $108^{\circ} 43^{\prime} 40,70^{\prime \prime} \mathrm{E}$ & 41,35 & 95007,98 & 39285,80 & 2000 & 157 & 15 \\
\hline
\end{tabular}




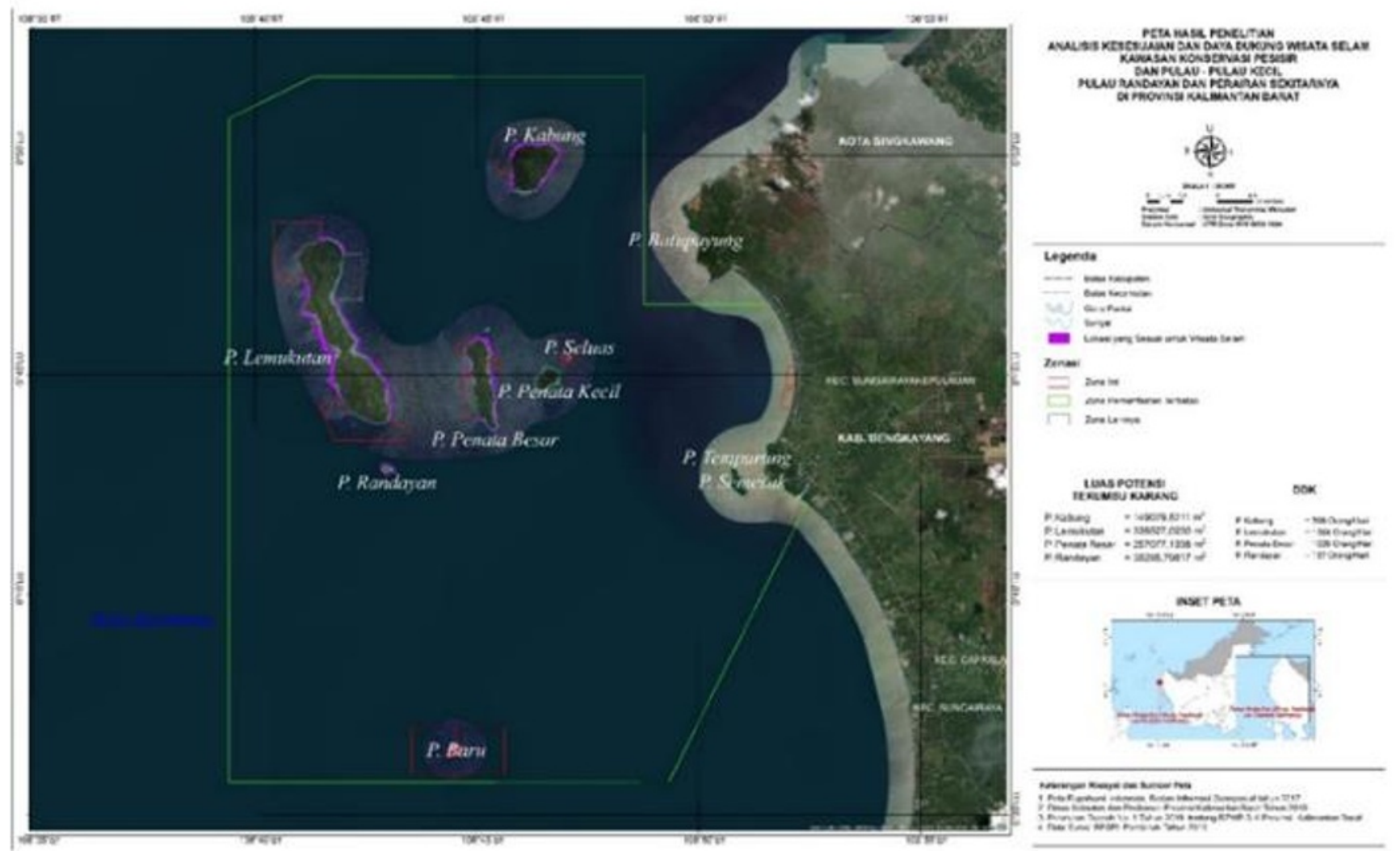

Figure 2. Map of Dive Tourism Suitability in Small Islands Park of Randayan Island and Surrounding Waters

\section{Conclusion}

The Tourism Suitability Index (IKW) for diving tourism in the Small Islands Park of Randayan Island limited use zone which consists of Station 1 (Kabung Island), Station 2 (Lemukutan Island), Station 3 (Penata Besar Island), and Station 4 (Randayan Island) are included in the Conditionally Suitbale category with the IKW scores of $65 \%, 56 \%, 72 \%, 65 \%$, respectively. The Carrying Capacity (DDK) for diving tourism activities in the limited use zone of the Randayan Island TPK and the Surrounding Areas in each research station (Kabung Island, Lemukutan Island, Penata Besar Island, and Randayan Island) respectively 596, 1,354, 1,028, 157 people per day with Utilization Carrying Capacity (DDP) 59, 135, 102, and 15 people per day, respectively. Coral rehabilitation efforts are needed in the Randayan Island TPK conservation area as an effort to increase coral community cover so that it can support sustainable diving tourism activities.

\section{References}

1. BPSPL Pontianak. Management and Zoning Plan for Coastal and Small Islands Protected Areas, Small Islands Park of Randayan Island, Bengkayang Regency. Pontianak: Ministry of Maritime Affairs and Fisheries. (2019).
2. Dermawan, A. et al. Guidelines for Drafting of Technical Plans for the Utilization of Marine Protected Areas. Jakarta: Ministry of Maritime Affairs and Fisheries. (2014).

3. Ginting, TR. Analysis of the Potential of Rempang Island and Galang Coastal Areas, Galang District, Batam City for Ecotourism Development. Thesis. Natural Resources and Environmental Management Study Program. Graduate School. Bogor Agricultural Institute. (2006)

4. Rosyidie A. Retrospect and Prospect of Tourism Development in Small Islands. In: Proceedings of the National Seminar on the Management of Coastal and Small Islands Ecosystems in the Context of Archipelago Countries. Yogyakarta, September 2, 2000. Yogyakarta: Publishing Agency, Faculty of Geography, Gadjah Mada University. (2000)

5. Rudianto, A., Dewi, YSK., And Burhanuddin. Ecotourism Development ff Snorkeling and Diving Activity Toward Coral Reef Habitats in The Lemukutan Island of Bengkayang Regency. AQUASAINS (Journal of Fisheries and Aquatic Resources) (Vol 8 No.2 of 2020)

6. Wardiyanta.. Tourism Research Methods. Yogyakarta: ANDI. (2006)

7. Yulianda, F and Atmadipoera, AS. Supporting Capacity and Ecotourism Management Plan for Marine Protected Areas Case Model: Thousand Islands National Park. Bogor: IPB (2019)

8. Yulianda, F. Aquatic Ecotourism, A Concept of Suitability and Support for Marine Tourism and Freshwater Tourism. Bogor: IPB Press. (2019) 
9. Yulius, et al.. Guidebook on Criteria for Establishing Marine Ecotourism Zones. Bogor: IPB Press. (2018)

10. Yusiana, LS.. Planning for Sustainable Coastal Tourism Landscape in Konga Bay, East Flores, East Nusa Tenggara. Thesis. Landscape

Architecture Study Program, Postgraduate School, Bogor Agricultural Institute (2007) 